Relations industrielles

Industrial Relations

\title{
IV - The Methods of Reform in Structure Proposed Solutions (continued)
}

\section{Marcel Clément}

Volume 3, numéro 9, mai 1948

URI : https://id.erudit.org/iderudit/1023634ar

DOI : https://doi.org/10.7202/1023634ar

Aller au sommaire du numéro

Éditeur(s)

Département des relations industrielles de l’Université Laval

ISSN

0034-379X (imprimé)

1703-8138 (numérique)

Découvrir la revue

Citer cet article

Clément, M. (1948). IV - The Methods of Reform in Structure: Proposed

Solutions (continued). Relations industrielles / Industrial Relations, 3(9),

142-144. https://doi.org/10.7202/1023634ar

Tous droits réservés @ C Département des relations industrielles de l’Université Laval, 1948
Ce document est protégé par la loi sur le droit d'auteur. L'utilisation des services d'Érudit (y compris la reproduction) est assujettie à sa politique d'utilisation que vous pouvez consulter en ligne.

https://apropos.erudit.org/fr/usagers/politique-dutilisation/ 
vergences d'intérêt qui opposent le Capital et le Travail et à faire naître l'esprit de solidarité, non seulement entre les membres actifs de l'entreprise mais encore entre les propriétaires du capital, la direction et le personnel.

\section{Conclusions}

Une quatrième journée aura aussi pour but d'établir le bilan des différents facteurs de solidarité étudiés et de tracer le programme de travail des conférences futures.

Cette Conférence d'études tendra ainsi à mettre au service de l'industrie et des gouvernants, les techniques propres à développer la solidarité de tout le personnel des entreprises, facteur certain de prospérité et d'équilibre.

\section{Proposed solutions}

(Continued from page 144)

interest. The case of the share-holders is more complicated. All depends on the respective importance of the services rendered by Capital and by Labour. And this importance varies with the economic maturity of the enterprise. At the time of incorporation Capital is more important than Labour. When the enterprise, as they say, «Goes along by itself », the importance of Capital decreases, although, sharing in the losses while Labour does not, it occasionally re-occupies a place of prime importance. The determination of Capital's share then shall be fixed according to the services rendered by it - such things as the furnishing of the means of work, the upkeep and the renewal of materials and stock, the financing of salaries, etc.

The surplus constitutes the share of Labour. One sees that in application such a structure is workable. But, it supposes, from the first, a reasonable desire to work together. But all the formulae studied tend to facilitate this collaboration rather than to suppose it obtained. And, doesn't Monsieur Dubois reason a little in the manner of the mathematician who assumes from the first that the problem is resolved?

\section{III-The Proportional Wage}

\section{(Schueller System)}

It was from his reflexions on the crisis of 1929 and on the after-effects which it produced upon the affairs he directed that Monsieur Eugène Schueller drew his idea of the proportional wage. Tried out somewhat tentatively before the war of 1939 it has been successfully extended to some hundreds of enterprises since 1940.

Monsieur Schueller does not start so much from a social point of view as from a concern with economic equilibrium. Much impressed by the development of mechanisation and by the problems which it poses, he strives to establish a constant between mechanized production and the purchasing power of the consumers (who are all in a certain sense, wage-earners). To attain this he intends to substitute for a theoretical rythme of progress in a «liberal» economy fixed wages, falling prices - a useful regulating device - fixed prices, rising wages.

For this end it is enough, in practice, to proportion systematically the total of the wages distributed in a given period to the monetary cxpression of production, i.e. to the turnover (or total of sales) during the same period. If, for example, it is observed that the proportion $-\frac{\mathbf{W}}{\mathbf{T}}$ equals $10 \%(100,000$ francs wages for $1,000,000$ turnover) expresses the proportional wage the decision is taken to declare to the personnel "From now on, your basic wages being assured whatever happens, you will always receive $10 \%$ of the turnover». If the turnover increases to $2,000,000$ the total sum of wages distributed will increase from 100,000 to 200,000 francs.

It is understood that in the enterprises where the turnover varies very much from one month to another the coefficient of proportion of wages to «turnover» will be determined according to the annual averages and over the greatest possible number of years. In this work the factors of irregularity and their interpretation are the subject of research. After which, it is simple, in applica. tion, to make a reserve in good months in order to lessen too great inequalities of wages in poor months.

On these bases Monsieur Schueller advocates four shares or rather, four wages:

First Wage: The wage guaranteed by collective agreements or labour contracts, which we usually call the basic wage.

Second Wage: The social wage which includes family allowances, social insurance, retirement, paid holidays, etc. When the State is responsible for many of these allocations it is this second wage which permits the 
enterprise concerned to supplement indemnities it may consider insufficient.

Third Wage: This is the monthly compensatory reserve which equalizes the poor months by the good ones.

Fourth Wage: This is the real proportional wage - that which is distributed among the workers in proportion to a basic wage.

Thus we see that the functioning of the proportional wage is extremely simple. Once the coefficient of proportionality is worked out and one knows that henceforth there will be $10 \%$ of the turnover to distribute in wages, each month the amount equivalent to this $10 \%$ will be distributed in function with the four wages paid to each worker. The determination of the basic wage is automatic. It depends directly on past contracts. In the same way the determination of the second wage is the result of the decisions taken by each individual enterprise to deposit such a complementary amount per living child and so on. The third wage - the reserve - is to be determined each month in function with the monthly inequalities and with the purpose of always guaranteeing, not only the first but also the second wage. After these three successive operations the remainder constitutes the fourth wage whose total amount is distributed each month in proportion to the basic wage.

What to think of such a formula!

The proportional wage accords to the wageearner guarantees more easily controlled perhaps than those of profit-sharing. This is its great advantage. The turnover is a simple datum, declared each month, recognized by the accountancy department and easily conveyed to the personnel. It is «unfakable». The proportion $\frac{w}{T}$ is a real proportion which one can take as standard. The volume of wages in the turnover although variable according to the nature of enterprise, within each one of these taken separately, really corresponds to an observable fact which avoids disputes.

This acknowledged, does the Proportional Wage fulfil its object as an economic wage formula? Does that share of Labour which it defines satisfy the workers' thirst for fairness and equity? Do they demonstrate this by a spontaneous transformation of their attitude and by their increased production? This is a very delicate point to clear up because of the characteristics of the period during which the some hundred experiences were in progress.

Indeed, if one refers to the turnover graphs of the enterprises applying the proportional wage one notes a rise more or less rapid and more or less constant according to the enterprise, but, general and sustained. However, the interpretation of these curves calls for several remarks.

On the one hand, the German occupation authorities as we know, had had a consistant policy of wage blocking. Many employers with the tacit approval and sometimes even under the instigation of the Labour Inspector, searched for methods to bestow concealed raises and certain ones, in order to attain this, were happy to profit by the setting up of the Proportionate Wage in their enterprise. The rate of turnover increasing, it was enough to tie in with it the rate of wages to have these later increase automatically. At the time of the establishment of the system in an enterprise it was even possible to partially adjust the wage-lag by setting the reation - $\frac{\text { wage }}{\text { Turnover }}-$ above its real value. Thus, under cover of a formula which was not at all suspect, it was possible to evade the ordinances in force and thus render very real service. In the same way, the certain increases in price which took place had almost negligible repercussions on wages. There is no question, be it understood, of explaining increases of fifty and a hundred percent only by this first impulsion. It should however, be mentioned.

On the other hand, the ultimate purpose of the proportionate wage is to distribute to Labour its share, in Monsieur Schueller's conception, that which returns to the wage-earner from an increased amount principally due to mechanisation. (We do not believe we are giving him away by saying «principally» since his avowed end is to guard against overproduction beyond a doubt more a factor as mechanisation progresses).

Now, in the greater part of the applications made, it is not an effort of mechanisation which is translated into wage-increases but almost entirely, a human effort of ingenuity, of time gained and of good will.

One can then state that, in every way, the proportional wage results in increased production and in economies of time which profit everyone. However, if the formula has this economic scope, because of its very character, one can doubt if it has a social scope as considerable as that of simple Profit-Sharing. 


\section{PROPOSED SOLUTIONS \\ (continued) \\ Marcel CLÉMENT}

We have thought it worth while to examine profit-sharing first of all in one of its more recent manifestations, because this still remains the "clas sic» solution of the problem. But, in modern times, many other schemes have been tried out!

\section{II-Income Sharing \\ (Dubois' System)}

One of the traditional difficulties in the sharing of profits is the very uncertainty as to just what «profit» means. When an enterprise follows an involved commercial policy the profit is determined largely, by the anticipations, the suppositions and the far from certain results of current undertakings. By this theoretical argument, Monsieur Dubois does not, of course, dispute the worthwhileness of the experiment of Monsieur Romanet and his imitators, but he does suggest that distribution can give rise to disputes in some circumstances. Starting from this assertion, Monsieur Dubois proposes what he calls «income-sharing», while he willingly acknowledges that one can apply «profit-sharing with success » particularly when the factors of uncertainty in the setting-up of the bonus, are trifling.

«Income 》 as he sees it, is composed of all percentages of profit, dividends, emoluments, wages and their supplements - in a word, everything which the furnishers of either capital or labour might receive. It is on the basis of this apportionment that the sharing operates.

The participation of the personnel is worked out by agreeing that to each 100 monetary units distributed to the shareholders will correspond $(x)$ monetary units to be distributed to the workers. (x) varies following the nature of the enterprise.

According to the author, the advantage of this mechanism is that it easily convinces the workman, who otherwise tends to remain suspicious of an employer whose only interest, he believes, is to reduce salaries in order to increase profits.

regime:

Two principal difficulties stand in the way of applying such a conception in a capitalist

1) How regulate the problem of reserves and of self-financing.

2) How determine capital's share if this share is no longer the profits as such.

The first difficulty is overcome in a way which Monsieur Dubois himself qualifies as «audacious». Defining the «income» as the proceeds of sales less the amounts due to suppliers and to security reserves, he is led to ask for the distribution of sums which normally would not be paid out but reserved for improvements - in a word, for self-financing. Monsieur Dubois proposes the distribution of these sums, esteeming it unjust that Capital alone should benefit from a surplus gained for the enterprise by the efforts of the workers.

Theoretically, these later are free to re-invest this money and so permit an increase of capital, but this is to ask of them a sacrifice which the greater number would consent to only with difficulty. Let us acknowledge that this method does not seem to us to be worth that of Monsieur Romanet who, when a policy of developing the enterprise entails the re-investment of a part of the profits, effects this re-investment but enters in the bonus book the amount due back to each worker - which amount carries interest. This difference is clear. Monsieur Romanet safeguards the autonomy of the commercial policy of the enterprise while associating labour with the dividends furnished by all increase in capital. Monsieur Dubois, on the other hand, distributes this capital and subordinates all growth of the enterprise to a voluntary subscription on the part of the workers.

The second question raised by Monsieur Dubois's system and which he considers himself at great length, is the choice of a criterion with a view to determine the share of capital if this share is no longer the profit. For the bondholders the problem is easy: they retain the right to a fixed 